\title{
INVESTOR CONFIDENCE, CORPORATE GOVERNANCE, STOCK LIQUIDITY AND DIVIDEND POLICY
}

\author{
Muhammad Rizwan ${ }^{1}$ \\ Middlesex University, $U K$ \\ Muhammad SadiqShahid ${ }^{2}$ \\ Bahauddin Zakariya University, Multan \\ Muhammad Hassan Bucha 3 \\ Bahauddin Zakariya University, Multan
}

\begin{abstract}
Purpose: The objective of this study is to examine the impact of investor confidence, corporate governance and stock liquidity on dividend policy of firms listed on Pakistan stock exchanges from 2010-2015. The liquidity constraint enabled a superior association with the interests of the controlling shareholders, particularly outside investors, which make a significant enhancement in firms' liquidity and governance. Findings: Our results indicate that dividends have a less significant impact on investor confidence after the corporate governance.

Practical Implication: Our interpretation is that the improvement in corporate governance, especially the improvement in the alignment between growth opportunities and cash dividends, may take longer time to emerge. These findings provide strong evidence that shift in corporate governance and stock liquidity influence dividend policy of a firm in a substantial manner. Another implication is that stock liquidity matters in firms' dividend decision making; the liquidity deficiency is compensated by large cash dividends.
\end{abstract}

Keywords: Dividend Policy, Corporate Governance, Investor Confidence and Stock Liquidity

INSPEC Classification : A9555L, A9630, B5270

\footnotetext{
* The material presented by the author does not necessarily portray the viewpoint of the editors and the management of the Institute of Business \& Technology (IBT)

${ }^{1}$ Muhammad Rizwan

2 Muhammad SadiqShahid

:mriz@hotmail.com

:sshahidmalik@bzu.edu.pk

${ }^{3}$ Muhammad Hassan Bucha

:hassanbucha@bzu.edu.pk

(C) IBT-JBS is published by the Institute of Business and Technology (IBT) Main Ibrahim Hydri Road, Korangi Creek, Karachi-75190, Pakistan.
} 


\section{INTRODUCTION AND BACKGROUND}

The corporate governance and stock liquidity is very important and they significantly influence the dividend policy. However it is important to understand that why do firms pay dividends? Miller and Modigliani (1961) are of the view that a firm's investment policy is an important factor in determining the dividends; and the dividend is merely the residual between earnings and investments. However, there is little evidence that managers and markets $(M \& M)$ do care about dividends, and that firm value does change in a consistent manner with dividend policy. The dividend literature in the last few decades has attempted to reconcile the M\&M irrelevance theorem with the empirical evidence, by relaxing the assumptions on which the irrelevance proposition is based. Most of them consider the role of corporate governance (Agency relationships), asymmetric information and taxes. Particularly, agency theory points out that an increase in dividends mitigates the agency problem and is favourably received by investors since managers will have less free cash flows to invest in projects with negative net present value, leading to higher firm value (Easterbrook, 1984; Jensen \&Meckling, 1976). The assumption embedded in the original M\&M proposition is that investors have no stock liquidity constraint. When capital markets are perfect, and there is no asymmetric information, trading is frictionless so that investors with liquidity needs can generate domestic dividends at no cost by selling an appropriate amount of their holdings in the firm. However, trading is not frictionless in the real financial markets. Investors eitherhave to offer a price allowance for an instant execution, or wait for an optimal execution.In the extreme form, the existence of trading constraints does not allow investors freely sell their shares in the secondary market to satisfy their liquidity needs. In the less excessive form, investors need to account for liquidity costs in the possible liquidation of the stocks. This paper examines how corporate governance and stock liquidity effect corporate dividend payouts and how investors' confidence can be enhanced. The corporate governance reforms in the capital stock market is a result of exogenous shock to firms' governance that enabled a better association with controlling interests of shareholders, particularly external investors, resulting in an improvement in firms' corporate governance. At the same time, these reforms removed a substantial trading constraint. Consequently, stock liquidity is more closely related to controlling shareholders' interests after the reform because they could sell some of their shares for liquidity needs and could also benefit from share price appreciation. We investigate the implications of the share-reform-induced governance and liquidity improvements in corporate dividend policy. First, we examine how listed firms' dividend policy influenced by the shock as results of corporate governance reforms and stock liquidity comparing with the dividend policy after these reforms. Secondly, we explore the channels through which the investor affects corporate dividend policy by considering the consequence of stock liquidity and corporate governance. This point of view about the effect of stock liquidity on dividends is relatively new, partly because non-tradability is not such an issue in the more mature markets.

As La Porta et al., (2000) investigate the cross-sectional corporate governance effect, where they propose two agency models of dividends (outcome and substitute models). 
Specifically, the "outcome model" hypothesizes that dividends result from minority shareholders using their legal powers to extract cash from corporate insiders. Alternatively, in the "substitute model," the payment of dividends is a substitute when the legal protection of shareholders is absent. Due to the need to seek external finance at some time, firms pay dividends to build up their reputation for good treatment of shareholders. Like Mitton (2004) investigates dividend policies in emerging markets and concludes that better governed firms pay higher dividends. A limitation of the previous studies is that their results can be attributed to selection bias. For example, a firm could choose to improve its governance and hence the improvement is endogenously determined, which may affect any inference drawn. The majority of studies establish a link between dividend policy and stock market liquidity. Banerjee et al., (2007) show that firms with lower stock liquidity are more likely to pay dividends, interpreting this as a sign that investors view dividends and liquidity as substitutes.

Moreover, they point out that past liquidity is an important element of dividend initiations (exclusions) for individual firms, and sensitivity of firm value to innovations in aggregate liquidity reduces after dividend introductions. In stark contrast, Igan et al., (2010) suggest a reverse causality and an opposite relation that distributing cash can lead to increased stock liquidity by reducing adverse selection costs. The discrepancies between the two studies may originate from the lack of an exogenous setting, such as, we have here, and that can clearly identify the causal relation between stock liquidity and dividend policy.

The structural reform offers a unique setting which allows us to test the relationship between corporate governance, stock liquidity and corporate payouts for several reasons. First, the reform provides a quasi-natural experimental setting which allows us to compare the relationship in the pre- and post-reform periods. Second, the reforms were mandatory and dominated in the capital market. While these reforms altered the exchangeability in the whole market, relatively, there was a minimum effect on a firm's operating, financing, and investment opportunities. Thus, the reform provides us with a desired setting for the analysis. Third, by providing evidence from the Pakistani stock market, we improve our understanding about the importance of corporate governance and stock liquidity in emerging markets.

Corporate governance plays important role in the stock market expansion by escalating the flow of capital in the financial market. The financial crisis in East Asian countries attracted major interest in the importance of corporate governance in developing countries. In early 2002, corporate governance codes were initiated by the Security Exchange Commission of Pakistan, which was a major movement in corporate governance reforms in the country. These corporate governance codes incorporate many suggestions similar to international good corporate governance practices. The board of directors is a major reform which was enforced with the intention of this would be accountable to all shareholders and better disclosure, including improved all types of audits of listed firms.

India has an ample corporate sector registered as widely-held corporation according 
to the Companies Act. Since 2000, a series of regulatory reforms have transformed the Indian corporate governance framework and improved the level of accountability of insiders, fairness in the treatment of minority shareholders and stakeholders, board practices and transparency, especially, the securities regulator initiated a corporate governance section in the listing agreement that clarified many issues. Current endeavours to implement law and guideline improved investor confidence in the financial market. These are positive drivers of change which enhance the shareholder rights; though, law enforcement and implementation is still a major issue (ROSC, 2004).

These reforms represent an exogenous shock to improve corporate governance through an enhanced role for minority investors and a more vibrant market for corporate control. These reforms also removed a liquidity constraint, which in turn reduces controlling shareholders' demand for cash dividends. In addition, the ability for shareholders to trade their shares publicly aligns the controlling shareholder's incentives to firm value, leading to a reduction in the expropriating behaviour through large cash distributions.

In this paper, we study how corporate governance and stock liquidity affect dividend policy by investigating the impact of theCG reform on cash dividends, and how these reforms and liquidity enhance the investor confidence for investment. There are two ways through which these reform functions: a governance channel and a liquidity channel.By adding a significant restriction, the reform signify an exogenous shock to the firms' performance and enabled a better orientation to outside investors, so they are able to sell their shares in the market and thus can comprehend the advantages of stock price appreciation. This ability provides the shareholders controlling with an incentive take value-maximizing arrangements for firm altogether, including eliminating or reducing pinching behaviours through large cash distribution. Moreover, since controlling shareholders' ownership will be diluted through the conversion process, it becomes more costly for shareholders to benefit from dividend payouts. Therefore, cash dividends distributed for the expropriation purpose are expected to decrease after the wealth of shareholders. Accordingly, controlling shareholders tend to monitor managers more actively and provide more strategic advice. In addition, poorly-performing firms are more prone to be the targets of takeover.

We also investigate whether the investor confidence affects firms' decision to pay cash dividends. The result indicates that the propensity to pay cash dividends decreases significantly after the reform. Furthermore, in the post-reform period, there is a decrease in the probability of initiating a cash dividend and firms are more likely to omit a cash dividend. In addition, firms tend to pay a lower level in the post-reform period when they maintain the dividend payments.

Our paper makes a number of contributions, including contributes to the literature by examining the impact of corporate governance, investor's confidence and stock liquidity on dividend policy. Second, it also provide a policy guideline how investors can motivate and their confidence be increased towards investment in the firm. Third, we contribute by identifying the liquidity channel through which the $\mathrm{GC}$ reform exerts influence on firms' dividend policy. Most of the previous empirical studies focus on governance 
improvements, but there are few exploring the liquidity channel. Our study fills the gap in existing literature on the topic.

We come up with solution of following Research problems in this paper, $\S \quad$ Whether Response of dividend payout ratio to the Corporate Governance reforms differs across firm characteristics?

$\S \quad$ Greater post-reform reductions in cash dividend are expected in firms with high sales growth and liquidity?

$\S \quad$ Corporate Governance reforms impact on dividend payout ratio of FOF and non FOF?

The rest of the paper is organized as follows. Section II reviews the related literature and hypotheses development. The section III describes the data and sample. The section VI provides empirical findings and robustness check, and the last section concludes the paper.

\section{LITERATURE REVIEW}

Agency theory points out that an increase in dividends mitigates agency problems and is favourably received by investors since managers will have less free cash flows to invest in negative net present value projects, resulting in higher firm value (Easterbrook, 1984 and Jensen \&Meckling, 1976). Hence, agency theory predicts that cash dividend payments increase with free cash flow, but decreases with growth opportunities for the firm (Jensen, 1986). Consistent with these theories, the existing studies report that firms have higher cash holding are more likely to pay cash dividends. Given that agency problems are prominent in firms, the need of mitigating agency conflicts could partially motivate shareholder to prefer cash dividends.

Shleifer and Vishny (1997) argue that in many large companies around the world, conflicts of interest among outside investors, such as minority shareholders, and management may not be the major source of agency problems. Instead, agency problem can arise from the conflicts of interest between minority shareholders and controlling shareholders who can exert considerable influence on management's decision making. The controlling shareholders who control corporate assets can use these assets for a range of purposes that are detrimental to the interest of the minority shareholders. For example, they can divert corporate assets to themselves or implement corporate policies that yield them personal benefits of control at the expense of minority shareholders.

Recently, Pan et al., (2015) examine the impact of corporate governance and stock liquidity on dividend payout. They observe that the governance reform confiscated liquidity constraint; in the meantime, it helped an improved direction of the interests of shareholders. These initiate major developments in governance and liquidity of firms. They find that decrease in payouts is more noticeable for firms with higher liquidity and growth rates. When trading friction exists in financial markets, stocks that pay cash dividends allow investors to satisfy their liquidity needs with less or no trading, and thus enable them to mitigate trading costs. Therefore, in markets with trading frictions, 
investors tend to view dividends and liquidity as substitutes, which is the starting point of the "liquidity hypothesis of dividends". Consistent with this, Banerjee, et al. (2007) show that firms with less liquid shares are more inclined to pay dividends, compared to firms with most liquid shares. Igan, et al. (2010), however, suggest an opposite relationship that dividend-paying firms are associated with more stock liquidity. Their discrepancies may lie in the endogeneity issue that stock liquidity and dividend policy can be jointly determined by other forces. Both studies lack an exogenous shock that affects only the liquidity of the firm stock, but has no direct effects on dividend policy. By using the split-share structure reform as an exogenous shock to stock liquidity, our study avoids the potential inference problem.

The nature of ownership is believed to have a considerable impact on firms' dividend policy. In the context, previous studies document that family owned business pay higher cash dividends than non-family owned business (Al-Ghamdi\& Rhodes, 2015; Wu and Zhai (2013); Yu, Chen and Sun (2010); Najib, 2007; Yu \&Zhuo (2007); Omet, 2005 and Saidi, 2005).

The incentive to pay cash dividends is also different between state-controlled and privately controlled firms (Lv and Zhou (2005). Due to historical reasons, family owned firms are distinguished for their critical owner-manager agency problems because of the ownership rights and the delegation of management and monitoring functions to officeholders whose interests are not well aligned with those of the shareholders. Specifically, the cash flow rights in family-controlled listed firms do not belong to the family. As a consequence, there is no incentive for shareholders to actively participate in the management of family-controlled listed firms. The virtual absence of private shareholders, therefore, makes the supervision and monitoring of managers ineffective (Liao and Fang, 2005). In addition, family shareholders, typically have no relevant industry experience, so they lack the necessary skills to effectively monitor listed firms' managers, and they also lack the knowledge to provide strategic advice (Chen et al., 2009). Therefore, private shareholders have neither incentive nor the ability to efficiently monitor managers in listed firms. In this sense, the agency problem between private shareholders and management is very prominent in state-controlled firms, and the corporate governance in such firms is relatively weak.

In light of the above argument, family-controlled firms are believed to pay high cash dividends in order to limit the managerial entrenchment behaviour and reduce agency costs (Xu and Chen, 2006). By contrast, expropriation is less likely to be the incentive of large dividend payments in the family controlled firms.

In contrast, the firms that are controlled by private investors, controlling shareholders often install themselves or their representatives as the CEO or the chairman of the listed firm, so the management is actively monitored by these private shareholders. At the same time, these private controlling shareholders normally have detailed knowledge of the industry in which the firm operates, thus it is relatively easier for them to be involved in the management function and to monitor the hired managers more effectively (Chen, et al., 2009). Therefore, compared to family-controlled firms, agency problem 
associated with the separation of ownership and management is proportionately smaller in privately controlled listed firms. A much bigger concern in such firms is the expropriation incentive of controlling shareholders. Specifically, unlike family-controlled firms, privately-controlled firms are not subject to state monitoring and government intervention. Controlling shareholders thus have more opportunities to expropriate corporate wealth. More importantly, private controlling shareholders are likely to emphasis on maximizing stock prices. Therefore, cash dividends are more likely to be used as a means of expropriation in privately-controlled firms.

The research on the $\mathbf{C G}$ reform generally focuses on whether the $\mathbf{C G}$ reforms are associated with positive outcomes. Banerjee \&Duflo (2014) also report the impact of post reform on profitability, productivity and investments of the firm. Furthermore, some other studies focus on the effect of corporate governance on the structural reform process, in particular, the compensation paid to shareholders. With better governance standards, including stronger shareholder protection, shareholders are willing to accept a relatively lesser level of compensation (Harford et al., 2013). Evidence shows that the compensation ratio is negatively associated with firms, while Albuquerque \& Miao (2013) document that the better the external governance environment of the firm, the lower the compensation ratio.

The threat of being taken over provides managers with better incentives to increase efficiency and enhance firm performance. Hence, agency costs should decrease after the reform, and consequently, the need to pay dividends (as a means to curtail the agency problem) will also decline. $t$ is worthwhile to mention that since the corporate structure reform removed liquidity constraints of the firms and shareholders are able to receive both dividends and capital gains in the post-reform period. This allows investors to create 'home-made' dividends, which in turn reduces shareholders' demand for cash dividends (Pan, 2015).

Family-controlled firms in emerging markets are well-known for their acute owner-

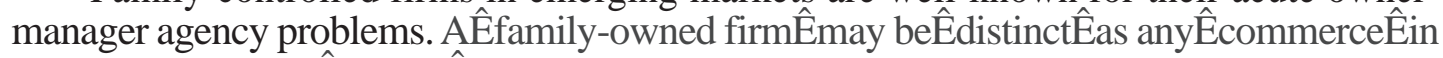
which two or moreÊfamilyÊmembers are concerned and the ownership and its command of is widely held by them. ÊIt's most previous form of business. Given the dual share structure, executives in the family-controlled firms would not behave in the best interests of shareholders. The shareholders do not have enough incentive to efficiently monitor managerial behaviours. This has fostered agency problems.

In contrast, for privately-controlled firms, controlling shareholders often install themselves or their representatives as the $\mathrm{CEO}$ or the chairman of the listed firm, so the management is actively monitored by these private shareholders. Therefore, privately-controlled firms are more efficient than family controlled firms and agency problems are relatively more severe for family-controlled firms. As argued by Sheshinski and López-Calva (2003), transferring family ownership to private ownership should result in significant efficiency gains.

The corporate governance reform dismantles the ownership structure in the stock market. For family-controlled firms, the reform unfreezes the transferring of ownership 
and effectively mitigates family shareholders' moral hazard problems by aligning their control and cash flow rights. Agency costs of family-controlled firms should decrease significantly after the reform. Therefore, in comparison with privately-controlled firms, family-controlled firms have less agency conflicts and would larger reductions in cash dividends payoutafter the $\mathrm{CG}$ reforms.

We also examine whether effect of corporate governance reform on cash dividends differs with firm-specific attributes that capture corporate governance and stock liquidity. Before the reform, as stated above, controlling shareholders generally preferred cash dividends, regardless of firms' growth opportunities, since the cash dividend payment was generally the primary source of return, given that their shares cannot be traded in the open market. Hence, paying cash dividends met large shareholders' demand, but consumed cash and reduced internal funds available for investment opportunities. The reform dismantled the dual-share structure and the wealth of large shareholders now becomes more closely tied to stock prices. Thus the payment of dividends can be directly affected by a firm's growth potential and investment needs. As a result, high-growth firms should tend to have a lower cash dividend payment after the reform. This conjecture also represents a governance improvement; therefore we can interpret it as a sign of the governance channel functioning.

Amihud and Mendelson (1986) suggest that the owners of illiquid shares incur additional trading costs. For instance, difficulty in selling an illiquid stock induces a high transaction cost. This results in a higher cost of capital, implying a lower stock price, should all other factors remain unchanged. The structural reform increased the share supply in the market and induced a negative impact on the liquidity of shares, especially in the post-lockup period. A firm with illiquidity prevents its shareholders from achieving expected capital gains and hence the shareholders prefer cash dividends. But contrast, for firms with more-liquid stocks, previously can be sold in the market relatively easily with less cost.

Therefore, controlling shareholders in more-liquid firms are more likely to sell their shares after the lockup, reducing their demand for cash dividends. Hence, firms with higher liquidity are expected to reduce cash payouts more after the reform. This expectation represents a direct outcome of the liquidity channel, given that the reduction in cash dividends is triggered by the liquidity shock.

\section{SAMPLE AND DATA DESCRIPTION}

The source of our data is DataStream, annual report of listed firms and stock exchange databases. Our sample includes all listed firms on stock exchanges in Pakistan from 2010 to 2015 . We remove all delisted firm and those whose data is unavailable and also exclude those dividend observations with a non-zero before-tax cash dividend, but with a zero after-tax dividend. Given that the reform compensation can take the form of a cash dividend, to avoid confounding, we discard the dividend observations occurring exactly in the reform year. Finally, a total of 6156 firm-year observations are included in our test sample, which represent 164 listed firms at Karachi stock exchanges over 
the sample period.

To investigate the effect of the corporate governance and liquidity on dividend payout, we employed the Pooled OLS model to estimate the results.Moreover, we also compare the change in dividend payouts between the family and private firms, and results are consistent with our expectation.

DIVit=á+â1CG it+â2Confit+â3BSIZE it+â4SG rowthit+â5 Illiquidityit+â6ROA it+ â7LEVit+â84ICFit+â9ROAVOLit+â10RE2TEit+ â11SIZEit +åit(1) DIVit=átâ1CG it+â2C onfit+â3BSIZE it+â4SG rowthit+â5 Illiquidityit+ â6ROA it+ â7L EVit+â84ICF it+â9ROAVOL it+â10RE 2TE it+ âl1R eformit*F OFit+â12SIZE it +åit(2)

DIVit=á+â1CG it+â2Confit+â3BSIZE it+â4SG rowthit+â5I lliquidityit+â6ROA it+ â7L EVit+â84I C F it+â9R OAVOL it+â10R E 2TE it+â11R eformit*SG rowthit+â12SI ZEit+åit(3)

DIVit=á+â1CG it+â2Confit+â3BSIZE it+â4SG rowthit+â5Illiquidityit+â6ROA it+ â7L EV it+â84ICF it+â9ROAVO Lit+â10R E 2TE it+â11R eformit*llliquidityit+âl2S IZEit+åit(4)

Where; DIVitis the dividend payout ratio (dependent variable), which is measure as the total cash dividends divided by the EBIT. Confiit is investor confidence in firm i in time t, SGrowthitis the annual average sales growth rate, over the period of time. Illiquidity is a liquidity ratio, which is measure as the ratio of the average daily return to the trading volume on that day. FOF is a proxy equal to 1 if the firm's controlled by family owned shareholder and otherwise 0 . In addition, aset of control variables are used as determinants of dividend payouts, including; ROAVOLitis the standard deviation of $R O A$ over the most recent four years including the current financial year. It is to proxy for cash flow uncertainty.RE2TEit the proxy for the earned to contributed capital mix and is measured as the retained earnings to total equity ratio. LagPayoutitis the cash dividend payout ratio in the prior year. Other control variables are as follows; FISZEit is firm size which is measured by the logarithm of total assets; firm operating profitability (PROFT) that is measured by return on assets; cash holding that is measured by cash and marketable securities plus short-term investments scaled by total assets and leverage (LEVit) which is measured by the total liabilities scaled by total assets. Moreover, to capture the actual effect of the corporate governance reform, we construct an indicator variable Reformit, which is equal to 1 if firm $i$ have finished the reform by the end of year $t$, and 0 otherwise.

Table 2 provides descriptive summary statistics for dividend payout variable as well as other key variables used in our later analysis. Panel 1 provide summary statistics for the whole sample. It shows that dispersion in cash dividend payouts account for $16.1 \%$ of the sample firm's average earnings, but the maximum payout ratio dispersion is as high as $90.3 \%$ when we talk about investor confidence in FOF and Non FOF. The mean values for overall sample lies in $52.67 \%$ which is appropriate. Discussing results of 
panel B and C sales growth is high and illiquidity ratio is concluded fewer in private controlled firms but in turn cash dividend mean going to be less due to more attractiveness in shares ownership interest over cash dividend because investor are more confident to invest. This suggests that on average, Pakistani listed firms divide less amount of earnings as dividends, however few firms pay higher amount of dividends. The results in table 2 indicate that on average, firms pay higher dividends than family owned firms which are consistent with the evidence in previous studies. The investors have more confidence to invest in non-family owned firms as compare to family own firms. Overall, non-family owned firms growth is higher than others firms and liquidity is lower, while return on investment also more than family own firms.

\section{EMPIRICAL RESULTS}

To investigate the effect of the corporate governance, investor confidence and liquidity on dividend payout, we used pooled OLS methods to estimate the results of sample data. Table 4summarize finding from equation (1). Model1 and Model 2 present the results of the baseline model. The coefficient ofReform is 0.05629 , which is highly significant at $1 \%$ level. This confirms that the reform leads to boost firms' dividend payout ratio and provides strong support to our first hypothesis. As results, investors confidence increase and they invest more in firms. Among others, SGrowthandIlliquidity has a significant association with dividend payout ratio. This implies that in general, firms appear not to take much account of growth opportunity and stock liquidity when determining their payout ratios. As to the control variables, all the coefficients are associated with the expected signs, which are aligned with those documented in the existing literature. For example, both size and profitability have a positive effect on dividend payout ratios, confirming the result by Fama and French (2001).The coefficient of board size has a significant association with dividend payout ratio; it means that family-owned firms pay a higher level of cash dividends than privately-owned firms to reduce the ownership impact.

We include an interaction term, Reform ${ }^{*} F O F$ variable to capture the differential payout ratio response of a family-owned firm to the $\mathrm{CG}$ reform. The coefficient for Reform *FOFis negative and significant, suggesting that family controlled firms experience a greater reduction in the cash dividend payout ratio after the reform, compared to privatelyowned firms. Thus, our second hypothesis is supported.To test whether the response of payout ratio to the reform differs across firm characteristics, we add Reform dummy with firm characteristics in Model 3 and Mdel4 (i.e., sales growth rate (SGrowth) and illiquidity ratio (Illiquidity), respectively). Several patterns are observed. First, Reform is still associated with a negative coefficient, confirming that firms' cash payouts drop in the post-reform DeAngeloet al., (2006) document that firms' propensity to pay dividends is higher when a higher percentage of retained earnings are added in total equity. 
The coefficient on Reform*SGrowthis also significantly negative, hence the higher the firm's growth rate, the greater the reduction in cash payouts after the reform. Similarly, Reform*Illiquidity exhibits a significant positive impact, implying that the firms with higher stock liquidity give rise to a larger reduction in cash dividends. Taken together, these results lend strong support to our third hypothesis that greater post-reform reductions in cash dividends are expected in firms with higher growth rates and liquidity. Second, SGrowthper se is now positive and significant; however, the interaction term of Reform*SGrowth has a significant negative coefficient. This is not unexpected given that before the reform, because of potential weak corporate governance, the negative relationship between dividends and growth opportunity (indicated by the agency theory) is loose (even positive) in Pakistani listed firms. When the reform improved governance by mitigating free cash flow problem and expropriation behaviour, the previously distorted relation is corrected (reflected by the negative coefficient of Reform*SGrowth). Coefficients of lag payout are negatively significant for FoF but it seems to b positive and significant in NONFOF.Good governance for which compensation ratios and board size are proxies having coefficients positively significant for both and R2 values through Ordinary least square regression gave value of $61.78 \%$. Ratio of retained earnings to total equity is highly significant in both firm cases but more favourable in case of NONFOF so that these earning supposed to be consumed for paying dividend later. We interpret this result as evidence of the governance improvement associated with the reform. Last but not least, Illiquidity has a significant negative coefficient; however, once interacted with the Reform dummy, the coefficient becomes significantly positive. This indicates that in the post-reform period, high-liquidity firms are associated with lower cash payout ratios, but this association is opposite before the reform. Investors are allowed to sell freely their shares to achieve liquidity after the reform, so they tend to view stock liquidity and cash dividends as substitutes, hence a negative correlation can be observed. A possible explanation is that in more liquid firms, trading ability is of more value to shareholders and hence controlling shareholders demand higher cash dividends to compensate for forfeiting this trading ability. The reversal in the liquidity effect represents a liquidity improvement brought about by the reform. Taken together, the results suggest that both the governance channel and the liquidity channel are taking effect on firms' cash dividend policy during the reform. We conclude that corporate governance and stock liquidity affect corporate dividend policy in a way consistent with agency theory and the liquidity hypothesis of dividends.

To verify whether the reform has different effects on family-controlled firms and privately-controlled firms, we partition the whole sample into two sub samples by the nature of firms' ultimate controlling shareholders. The family owned firms sample consists of those firms whose ultimate controlling shareholder is family member, and non-family own firms sample consists of those firms that are controlled by private shareholders. For both samples, we estimatedresults by using OLS models, and results are reported in table 4 . The coefficients on Reformare significantly negative for both the family and non-family own firms samples. It suggests that listed firms experience a reduction in cash dividends after the reform, regardless of their ultimate controlling shareholders. This is expected given that the reform is a countrywide program in which 
every firm was required to participate. Additionally, we observed that Reform has a larger coefficient in magnitude for the Family sub sample, relative to the Private sub sample (0.066 versus 0.037$)$. This confirms the result in table 4 that the reform has a greater effect on the dividend payout ratio in the family controlled firms than in privatelycontrolled firms. Thus, our second hypothesis is supported.

Analysis also reports the estimation results of the full model which includes the interaction between Reform and SGrowth/ Illiquidity. Again, the coefficient on Reform is greater in magnitude (also mores insignificant) for the Family sub sample, compared to the NFOF sample ( 0.070 and 0.054 , respectively). When examining the interaction terms, we find some interesting patterns. In the Private sub sample, the interaction between Reform and SGrowthis significantly negative while SGrowthper se is positive.

Illiquidity coefficient is significantly negative, but the coefficient on Reform*Illiquidity is positive and highly significant. This is the same pattern as that we find for the whole sample in table 4. The similar pattern, however, is not observed in the Family sub sample. In other words, both the governance effect and the liquidity effect, we find in the whole sample are mainly driven by the response of privately-controlled firms. Privately-controlled firms are more likely to correct the previously distorted relationship between cash dividends and growth/liquidity after the reform. This is not unexpected given the differential objectives between family-controlled and privately-controlled firms. The nature of the corporate objective in family-controlled firms is shaped by the existence of the controlling shareholder's family objective function, for example, a wish to meet certain individual objectives. In contrast, controlling shareholders of nonfamily-owned firms would generally not be expected to have individual objectives, and their focal point is to enhance the wealth of shareholder through stock price maximization. Therefore, non-family-owned firms are expected to establish dividend policy in relation to their growth opportunities. On the other hand, in family-owned firms, due to the controlling rights consideration, the room for creating 'home-made' dividends to achieve liquidity by selling their shares is very limited, even though the reform has unfrozen the trading constraint. Consequently, after these reforms the substitution between cash dividends and stock liquidity turns out to remain weak in family owned firms.

In the analysis section, we used the relation between cash dividends and growth opportunities as a proxy for corporate governance quality, but this relation is more likely to be an outcome of governance rather than a direct measure. To explicitly investigate whether the effect of the quality of governance on dividends payout, we include a direct indicator of corporate governance in our analysis in this section. Goodgvnis a proxy for good corporate governance, which is a dummy variable that equals to one if the firm i's compensation ratio in the reform is below the sample median. This proxy for corporate governance is supported by many studies, which generally document that the better the governance level, the lower the compensation ratio (Jin and Yuan, 2008; Zhigang et al., 2007).This result is expected in the sense that 
the poorer the pre-reform governance, the greater the improvement after the reform, consequently the larger the decrease in cash payouts.

In table 5, we include an interaction Reform*FOF variable capturing the level of governance in family own firms. The coefficient on Reform*FOFis only marginally significant in this specification. This is not unexpected that family-controlled firms are more likely to be weakly-governed firms. As the governance measure Reform has proxy for the family-control nature in a large part, we observe asignificant coefficient on Reform*Family.

As we discussed earlier, the association between growth opportunities and cash dividends is a potential outcome of good governance. Naturally, direct controlling for the corporate governance level will make this association not as salient as before. Therefore, growth opportunities appear less important in determining the cash dividend ratio in this specification. The inclusion of governance measure, however, does not interfere with the liquidity effect.

Igan, et al. (2010) argue that good governance (e.g. shareholder protection) is a condition for stock liquidity to take effect on dividend policy by showing that the relationship between liquidity and dividends is stronger for firms with stronger shareholder power. The liquidity needs of shareholders should only matter in the decision to pay dividends if management takes into account their needs. So, if governance is highly concerned, the stock liquidity will not have huge effect on cash dividends. To concentrate on conjecture, we estimated the results; the coefficients on Reform are significantly negative. Even for firms with good corporate governance, the reform still influences their dividend policy. This confirms that the reform has a greater effect on the dividend payout ratio in firms with weaker pre-reform governance level.

Moreover, we interact the Reform dummy with the illiquidity ratio (Illiquidity) and we observe that Illiquidity has a negative coefficient, while Reform*Illiquidity is associated with a positive coefficient. In other words, the relation between stock liquidity and cash dividends has been reversed after the reform and the negative relation after the reform is more consistent with the liquidity substitution hypothesis of dividends (Banerjee, et al., 2007). Comparing the two sub-samples, we find that the shareholders' liquidity needs are less respected in weakly-governed firms. The result confirms our conjecture that if corporate governance is the dominant concern of management in making dividend payment decisions, shareholders' liquidity needs are less likely to be taken into account by management, and thus the reform-induced liquidity shock has a smaller impact on cash dividends in such firms. 
The estimation of the full model is reported in column 3. The inclusion of the other two interactions (i.e. Reform*Family and Reform*SGrowth) does not alter our main conclusion. The reversal of the liquidity-dividend relationship is less significant this is in line with our above conjecture. It is worthwhile to mention that Reform*FOFhas a significantly negative coefficient. This suggests that the difference between familyowned and privately-owned firms (in terms of the dividend-policy response to the reform) is mainly driven by well-governed family-owned firms. We also observe that the coefficient on Reform*SGrowthis significantly negative only in the both sub sample. Hence, growth opportunities have a strong effect on cash dividends only in wellgoverned firms. For weakly-governed firms this effect seems unapparent. The findings on the effect of family ownership and growth opportunities both corroborate that in firms with weak governance, management regards governance as the major concern when making dividend decisions; instead, neither the ownership nature nor growth opportunities have a crucial effect on dividend policy.

\section{CONCLUSION}

Good corporate governance practices build equilibrium between management and shareholders and eliminate agency problems; as a result managers pursue a suboptimal dividend policy. On the other hand, the reform removed a substantial trading constraint and relates stock liquidity closely with controlling shareholders' interest. In this paper, we examine the potential relationship between corporate governance, investor confidence and liquidity on dividend policy. The evidence exhibit that average cash dividend payout decreases significantly, and the reduction in payouts is more significant for firms with higher growth rates and for firms with higher liquidity. Investors inclined towards high share prices, which give them capital gains so in presence of high sales growth and in the position, a low payout ratio does not discourage the investors. These findings are consistent in the view that the reform is associated with improvements in firms' liquidity and governance, which have a significant effect on corporate dividend policy. In addition, due to the different characteristics and incentives of ultimate controlling shareholders between family-controlled and privately-controlled firms, a larger decline in cash dividends is observed in firms that are controlled by family shareholders. We also examine how firms' decision to pay cash dividends is affected by the corporate governance reform, and we find that firms are less likely to pay cash dividends in the post-reform period. The probability of initiating dividend as well drops significantly after the reform in NONFOF as per result statistics. Instead, firms are more likely to omit a dividend; when they choose to maintain their dividends, they appear to pay a lower level. Our results are robust to different time horizons around the reform.

Our findings provide strong evidence that corporate governance arrangement and stock liquidity shifts the effect of firms' dividend policy in a considerable manner. There are two important implications drawn from our findings. First of all, the split-share structure is associated with serious corporate governance problems and liquidity hazard; in that our results show that both the governance and liquidity are improved after the reform eliminates the dual share structure. 
Another implication is that stock liquidity matters in firms' dividend decision making. In the pre-reform period when the liquidity of controlling shareholders is restricted; the liquidity deficiency is compensated by large cash dividends. After the reform when the liquidity is greatly enhanced, instead, cash dividends become substitutes for liquidity.

\section{REFERENCE}

Albuquerque, R., \& Miao, J. (2013).CEO Power, Compensation, and Governance.ÊAnnals of Economics and Finance, $\hat{E} 14(2), 443-479$.

Amihud, Y., \& Mendelson, H. (1986). Asset pricing and the bid-ask spread. Journal of financial Economics, $\hat{E} 17(2), 223-249$.

Banerjee, S., Gatchev, V. A., \&Spindt, P. A. (2007). Stock market liquidity and firm dividend policy.ÊJJournal of Financial and Quantitative Analysis,Ê42(2), 369-397.

Banerjee, V., \&Duflo, E. (2014). Do firms want to borrow more? Testing credit constraints using a directed lending program.ÊThe Review of Economic Studies,Ê81(2), 572607.

Chen, G., Firth, M., \& Xu, L. (2009). Does the type of ownership control matter? Evidence from China's listed companies.ÊJournal of Banking \& Finance,Ê33(1), 171-181.

Chen, Q., Chen, X., Schipper, K., Xu, Y., \&Xue, J. (2012).The sensitivity of corporate cashholdings to corporate governance, Review of Financial Studies 25(12), 36103644.

DeAngelo, H., DeAngelo, L., \&Stulz, R. M. (2006). Dividend policy and the earned/contributed capital mix: a test of the life-cycle theory.ÊJournal of Financial economics, $\hat{E} 81(2), 227-254$.

Easterbrook, F. H. (1984). Two agency-cost explanations of dividends.ÊThe American Economic Review, 74(4), 650-659.

Fama, E. F., \& French, K. R. (2001). Disappearing dividends: changing firm characteristics or lower propensity to pay.ÊJournal of Financial economics,60(1), 3-43.

Jun, G. (2009). Study on the cash dividend policy of state-owned listed companies around the ownership reform,Communication of Finance and Accounting,27(9), $20-22$.

Gill, A., Biger, N., \&Tibrewala, R. (2010). Determinants of dividend payout ratios: evidence from United States.ÊThe Open Business Journal,Ê3(1), 8-14. 
Guo-liu, H. U., \& Huang, J. G. (2005). The Relationship Between Ownership Structure and Corporate Dividend Policy Choice: A Theoretical and Empirical Study [J].ÊJournal of Hanzhou University of Commerce, $\hat{E} 12,000$.

Harford, J., Mansi, S. A., \& Maxwell, W. F. (2013). Corporate governance and firm cash holdings in the US.ÊJournal of Financial Economics,Ê87(3), 535-555.

Igan, D., de Paula, A., \&Pinheiro, M. (2010).Liquidity and dividend policy, MPRA Paper No.29409.

Jensen, M. C. (1986). Agency cost of free cash flow, corporate finance, and takeovers.ÊCorporate Finance, and Takeovers. American Economic Review,76(2).

Jensen, Michael C, and William H Meckling, 1976, Theory of the firm: Managerial behaviour, agency costs andownership structure, Journal of Financial Economics 3(4), 305-360.

Jin, Qinglu, and Hongqi Yuan, 2008, Corporate governance and the determinants of the compensation ratio in the splitting-share reform, China Economic Quarterly 8(1), 249-270.

La Porta, R., Lopez-de-Silanes, F., Shleifer, A., \&Vishny, R. W. (2000). Agency Problems and Dividend Policies around the World.ÊThe Journal of Finance,55(1), 1-33.

Liao, L., \& Wan, F. (2005). The agency theory of dividend policy: an empirical analysis.ÊNankai Management Review (5), 55-62.

Lv, Changjiang, and Xianhua Zhou, 2005, Corporate governance and payout incentive - based on agency cost and tunneling, Nankai Business Review (in Chinese) 8(3), 9-17.

Michaely, Roni, and Michael R Roberts, 2012, Corporate dividend policies: Lessons from private firms, Review of Financial Studies 25(3), 711-746.

Miller, Merton H, and Franco Modigliani, 1961, Dividend policy, growth and the valuation of shares, The Journal of Business 34(4), 411-433.

Mitton, Todd, 2004, Corporate governance and dividend policy in emerging markets, Emerging Markets Review5(4), 409-426.

Pan, R., Shi, J., \& Zhu, Q. (2015).Dividend Policy, Corporate Governance and Stock Liquidity.Corporate Governance and Stock Liquidity.Available at papers.ssrn.com.

Pan, R. (2015). Essays on corporate dividend policy: Chinese evidence. Sheshinski, Eytan, and Luis F López-Calva, 2003, Privatization and its benefits: Theory 
and evidence, CESifoEconomic Studies 49(3), 429-459.

Shleifer, Andrei, and Robert W Vishny, 1997, A survey of corporate governance, The Journal of Finance 52(2), 737-783.

Wang, Huacheng, Chunling Li, and Chuang Lu, 2007, A case study of the impact of controlling shareholders onthe listed companies' cash dividend policies, Management World (1), 122-127.

Wu, Xiaoling, and MingleiZhai, 2013, Empirical study on influence of ownership structure on dividend policy -based on ownership structure changes after equity division reform, Journal of Shanxi Finance andEconomics University (in Chinese) 35(1), 84-94.

Xu, Liping, Yu Xin, and Gongmeng Chen, 2006, The types of controlling shareholders and the performance forchina's listed companies, The Journal of World Economy,10, 78-83.

Yu, J., CHEN, G. M., \& Sun, B. (2010). The influence of non-tradable share reform

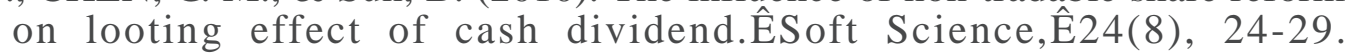

Yu, S. O. N. G., \&Zhuo, L. I. (2007).Ultimate Control Person's Characteristics and Cash Dividend Policy.ÊAudit \& Economy Research,Ê22(5), 025.

Zhigang, Z., Yanmei, S., Songtao, T., \&Dezeng, J. (2007). Consideration Determination in the Split-share Structure Reform and the Examination of the Effectiveness of Corporate Governance Mechanisms in China's Listed Companies.ÊEconomic Research Journal,Ê7, 011. 


\section{APPENDIX}

Table .1: Definition of all Variables those are included in this study

\begin{tabular}{|l|l|}
\hline Variable & \multicolumn{1}{c|}{ Definitions } \\
\hline Payout & dividends divided by EBIT \\
\hline Confidence & $\begin{array}{l}\text { Investors confidence indexes are constructed by using tumover growth rate of } \\
\text { individual stock }\end{array}$ \\
\hline BSIZE & The number of directors appointed by the shareholders on the board \\
\hline FOF & Equals one if the family shareholding in the firm is at least 25\%, and zero otherwise \\
\hline SGrowth & Annual average sales growth rate \\
\hline Illiquidity & $\begin{array}{l}\text { The average ratio of the daily absolute retum to the trading volume on that day, } \\
\text { averaged over the pre-reform years }\end{array}$ \\
\hline FISIZE & Logarithm of total assets \\
\hline ROA & Ratio of EBIT to total assets \\
\hline Cash & Cash and marketable securities plus short-term investments scaled by total assets \\
\hline Leverage & Ratio of total liabilities to total assets \\
\hline ROAVOL & Standard deviation of ROA over the recent 4 years, including the currentfinancial year \\
\hline RE2TE & Ratio of retained earnings to total equity \\
\hline LagPayout & Cash dividend payout ratio in the prior year \\
\hline Goodgvn & $\begin{array}{l}\text { Indicator variable that equals to one if firm i's compensation ratio is below the sample } \\
\text { median and zero otherwise }\end{array}$ \\
\hline
\end{tabular}

Table.2: Summary Statistics

This table presents descriptive statistics of all variables which are defined as in table 1. Our whole sample includes 164 listed firm from 2010-2015. Panel A reports the summary statistics for the whole sample. Panel B reports the summary statistics for the family own sample. The family own sample consists of those firms that controlled by family. Panel C reports the summary statistics for the Private controlled sample. 


\begin{tabular}{|l|l|l|l|l|l|l|}
\hline Variable & \multicolumn{3}{|l|}{ Panel A } & \multicolumn{2}{l|}{ PanelB } & \multicolumn{2}{l|}{ PanelC } \\
\hline & Mean & SD & Mean & SD & Mean & SD \\
\hline DIVPAY & 0.5267 & 0.161 & 0.4334 & 0.693 & 0.6201 & 0.516 \\
\hline Confidence & 0.4857 & 0.903 & 0.6234 & 0.057 & 0.348 & 0.065 \\
\hline BSIZE & 0.4450 & 0.045 & 0.3928 & 0.605 & 0.4980 & 0.503 \\
\hline SGrowth & 0.2525 & 0.056 & 0.2194 & 0.923 & 0.2864 & 0.950 \\
\hline Illiquidity & 0.2805 & 0.082 & 0.3520 & 0.380 & 0.2096 & 0.462 \\
\hline FSIZE & 0.3075 & 0.106 & 0.3489 & 0.109 & 0.2673 & 0.082 \\
\hline ROA & 0.1235 & 0.390 & 0.1086 & 0.823 & 0.1292 & 0.009 \\
\hline Cash & 0.3865 & 0.184 & 0.4094 & 0.693 & 0.3640 & 1.268 \\
\hline Leverage & 0.5890 & 0.266 & 0.5187 & 0.826 & 0.4829 & 0.745 \\
\hline ROAVOL & 0.2754 & 0.078 & 0.2486 & 0.746 & 0.3024 & 0.354 \\
\hline RE2TE & 0.1736 & 0.904 & 0.2508 & 0.482 & 0.0961 & 0.268 \\
\hline LagPayout & 0.0149 & 0.619 & 0.0164 & 0.628 & 0.0129 & 0.168 \\
\hline
\end{tabular}

Table.3: Pearson correlations Matrix Analysis between Dividend payout and others variables

\begin{tabular}{|c|c|c|c|c|c|c|c|c|c|c|c|}
\hline Variables & 1 & 1 & 3 & 4 & 5 & 6 & 7 & 8 & 9 & 10 & 11 \\
\hline \multicolumn{12}{|l|}{ 1.DIVPAY } \\
\hline 2 Conff & $0.249^{* *}$ & & & & & & & & & & \\
\hline 3 BSIZE & $0.396^{*}$ & $0.246^{* * *}$ & & & & & & & & & \\
\hline 4.SGrowth & $0.271^{*}$ & 0.286 & 0.175 & & & & & & & & \\
\hline SIlliquidity & $0.250^{*}$ & $0.351^{*}$ & $0268^{*}$ & $0.383 *$ & & & & & & & \\
\hline 6FIIZE & 0.243 & $0.324^{*}$ & $0.234^{*}$ & 0.345 & 0.126 & & & & & & \\
\hline $7 \mathrm{ROA}$ & $0.317^{* *}$ & 0.131 & $0.143^{* *}$ & $0.219^{*}$ & 0.170 & 0214 & & & & & \\
\hline 8Cash & $0.262^{*}$ & 0.351 & $0.139^{*}$ & 0.140 & $0.43]^{* *}$ & 0.326 & 0.233 & & & & \\
\hline 9.LEV & $0.187^{*}$ & $0.133^{* * *}$ & $0214^{*}$ & 0.313 & $0.274^{*}$ & $0268^{*}$ & $0.277^{*}$ & $0.141^{*}$ & & & \\
\hline 10ROAVOL & $0.424^{* *}$ & 0.236 & $0219^{*}$ & $0.083^{*}$ & 0.105 & 0.436 & $0.32 \%^{*}$ & $0.118^{*}$ & $0.039 \%$ & & \\
\hline 11.RE2TE & $0.282^{*}$ & $0.128^{* * *}$ & $0387^{*}$ & $0.299^{*}$ & $0.362^{*}$ & 0.541 & 0.236 & 0.050 & $0.047^{*}$ & 0.035 & \\
\hline 12.Lageayout & 0.148 & $0.136^{*}$ & $0.143^{*}$ & 0.059 & $0.198^{* *}$ & 0.236 & 0.246 & 0.047 & 0.392 & 0.042 & $0.064^{* *}$ \\
\hline
\end{tabular}


Table.4: Effect of corporate governance, investor confidence on Dividend Payout

This table presents the pooled OLS regression results regarding impact of corporate governance, investor's confidence and liquidity on firms' dividend payout ratio. Our whole sample includes 164 listed firms from 2010-2015. The dependent variable is Dividend Payout, Reform is a dummy variable and FOF is an indicator variable that equals to one if the firm's ultimate controlling shareholder is a family-owned-enterprise. SGrowthis the annual sales growth rate, averaged over the pre-reform years and Illiquidity is the average ratio of the daily absolute return to the trading volume. LagPayoutis dividend payout ratio in the prior year. ROAVOL is the standard deviation of ROA. RE2TEit is measured as the ratio of retained earnings to total equity. FISZE is firm size and leverage (LEVit), which is measured by the total liabilities scaled by total assets. We partition the whole sample into two sub-samples by the nature of firms' ultimate controlling shareholders. The family own firm sample consists of those firms whose ultimate controlling by family members and non-family own firms those are controlled by private entities. Standard error reported in parentheses. $* * *$ at $1 \%, * *$ at $5 \%$ and $* 10 \%$ levels of significance.

\begin{tabular}{|c|c|c|c|c|}
\hline Variable & $\begin{array}{c}\text { OLS } \\
\text { Model1 }\end{array}$ & $\begin{array}{c}\text { Fixed effect } \\
\text { Model2 }\end{array}$ & $\begin{array}{c}\text { FOF } \\
\text { Model3 }\end{array}$ & $\begin{array}{l}\text { NONFOF } \\
\text { Model3 }\end{array}$ \\
\hline Constant & $\begin{array}{l}0.16197 \\
(0.902)\end{array}$ & $\begin{array}{c}0.09486 \\
(0.086)\end{array}$ & $\begin{array}{c}-0.0549^{*} \\
(0.027)\end{array}$ & $\begin{array}{l}0.20169 \\
(0.934)\end{array}$ \\
\hline Confidence & $\begin{array}{c}0.03149^{*} \\
(0.028)\end{array}$ & $\begin{array}{c}-0.02960^{* * * *} \\
(0.019)\end{array}$ & $\begin{array}{c}-0.03907^{*} \\
(-1.56)\end{array}$ & $\begin{array}{c}0.02028 \\
(0.352)\end{array}$ \\
\hline BSIZE & $\begin{array}{l}0.03629 \\
(0.450)\end{array}$ & $\begin{array}{c}0.03094^{* * * *} \\
(0.003)\end{array}$ & $\begin{array}{c}-0.04692^{* * *} \\
(-0.018)\end{array}$ & $\begin{array}{c}0.02964 * * * \\
(0.009)\end{array}$ \\
\hline Reform & $\begin{array}{c}0.05629 * * * \\
(-0.020)\end{array}$ & $\begin{array}{c}0.06047^{* * *} \\
(-0.004)\end{array}$ & $\begin{array}{c}-0.06189^{* *} \\
(0.028)\end{array}$ & $\begin{array}{c}-0.05946^{* * * *} \\
(-0.024)\end{array}$ \\
\hline SGrowth & $\begin{array}{c}-0.02039 \\
(0.710)\end{array}$ & $\begin{array}{c}-0.02864^{* * * *} \\
(0.002)\end{array}$ & $\begin{array}{c}-0.02368^{* * * *} \\
(0.006)\end{array}$ & $\begin{array}{c}-0.01749 \\
(0.529)\end{array}$ \\
\hline Illiquidity & $\begin{array}{l}0.03826 \\
(0.916)\end{array}$ & $\begin{array}{c}0.03269 * * * \\
(0.0159)\end{array}$ & $\begin{array}{c}-0.04518^{* * *} \\
(-0.019)\end{array}$ & $\begin{array}{l}0.02193 \\
(0.634)\end{array}$ \\
\hline FSIZE & $\begin{array}{c}-0.03186^{*} \\
(0.029)\end{array}$ & $\begin{array}{c}0.02894 * * \\
(0.013)\end{array}$ & $\begin{array}{c}0.04169^{* *} \\
(0.014)\end{array}$ & $\begin{array}{c}0.03284^{*} \\
(0.019)\end{array}$ \\
\hline $\mathrm{ROA}$ & $\begin{array}{c}0.02879^{* * *} \\
(0.000)\end{array}$ & $\begin{array}{l}0.03865 \\
(0.096)\end{array}$ & $\begin{array}{c}-0.03796^{* * * *} \\
(-0.008)\end{array}$ & $\begin{array}{c}0.03086 * * * \\
(0.000)\end{array}$ \\
\hline Cash & $\begin{array}{c}-0.04847 \\
(1.336)\end{array}$ & $\begin{array}{c}-0.04079 \\
(0.820)\end{array}$ & $\begin{array}{c}0.03195^{* * *} \\
(-0.012)\end{array}$ & $\begin{array}{c}0.06328^{*} \\
(0.032)\end{array}$ \\
\hline Leverage & $\begin{array}{c}-0.05809 \\
(1.964)\end{array}$ & $\begin{array}{c}-0.02846 \\
(5.302)\end{array}$ & $\begin{array}{c}0.03696 * * * \\
(0.009)\end{array}$ & $\begin{array}{c}-0.06782 \\
(1.906)\end{array}$ \\
\hline$R O A V O L$ & $\begin{array}{c}0.03896^{* * *} \\
(0.001)\end{array}$ & $\begin{array}{c}0.05086^{* * * *} \\
(0.025)\end{array}$ & $\begin{array}{c}0.0387^{* * *} \\
(0.031)\end{array}$ & $\begin{array}{c}0.05896^{* * *} * \\
(0.020)\end{array}$ \\
\hline$R E 2 T E$ & $\begin{array}{c}0.03068^{* * *} \\
(1.176)\end{array}$ & $\begin{array}{c}0.03594^{* * * *} \\
(0.001)\end{array}$ & $\begin{array}{c}0.02629^{* * * *} \\
(0.006)\end{array}$ & $\begin{array}{c}0.03649 * * * \\
(0.000)\end{array}$ \\
\hline LagPayout & $\begin{array}{c}-0.04285^{* *} \\
(0.008)\end{array}$ & $\begin{array}{c}0.04386^{* * *} \\
(0.018)\end{array}$ & $\begin{array}{c}-0.02729^{* * *} \\
(-0.008)\end{array}$ & $\begin{array}{c}0.04387 * * \\
(0.018)\end{array}$ \\
\hline Goodgun & $\begin{array}{c}0.13859 * * * \\
(0.067)\end{array}$ & $\begin{array}{c}0.18264^{* * *} \\
(0.047)\end{array}$ & $\begin{array}{c}0.16529 * * * \\
(0.023)\end{array}$ & $\begin{array}{c}0.12098^{* * *} * \\
(0.048)\end{array}$ \\
\hline $\mathrm{R} 2$ & $61.78 \%$ & $72.96 \%$ & $49.67 \%$ & $49.67 \%$ \\
\hline
\end{tabular}


Table.5: Corporate Governance and Effect of the Reform

The table compares firms' three-year average cash dividend payout ratio before and after the split-share structure reform. Our whole sample includes 164 listed firms observations from 2010-2015. The Family sub sample consists of those firms whose ultimate controlling shareholder is family. Panel $\mathrm{C}$ reports the change for the Privates ubsample. The NFOF sub sample consists of the firms that are controlled by private entities. T-statistics are reported in parentheses. $* * *, * *$ and $*$ denote significance at $1 \%, 5 \%$ and $10 \%$ levels, respectively.

\begin{tabular}{|c|c|c|c|c|c|}
\hline Variable & $\begin{array}{l}\text { FOF } \\
\text { Model1 }\end{array}$ & $\begin{array}{l}\text { NFOF } \\
\text { Model2 }\end{array}$ & $\begin{array}{l}\text { FOF } \\
\text { Model3 }\end{array}$ & $\begin{array}{l}\text { NFOF } \\
\text { Model4 }\end{array}$ & $\begin{array}{l}\text { OLS } \\
\text { Model5 }\end{array}$ \\
\hline Payout & $\begin{array}{l}0.2804^{* * * *} \\
(46.16)\end{array}$ & $\begin{array}{l}0.4358^{* * *} \\
(0.31)\end{array}$ & 0.4028 & $\begin{array}{l}0.3684 \\
(0.965)\end{array}$ & $\begin{array}{l}0.2614 * * * \\
(0.078)\end{array}$ \\
\hline INS & $\begin{array}{l}-0.065^{* *} \\
(-12.25)\end{array}$ & $\begin{array}{l}0.124 * * * \\
(20.31)\end{array}$ & $\begin{array}{l}0.040 * * * \\
(-3.98)\end{array}$ & $\begin{array}{l}0.164^{* * * *} \\
(20.32)\end{array}$ & \\
\hline Reform & $\begin{array}{l}-0.0405^{* *} \\
(-0.002)\end{array}$ & $\begin{array}{l}-0.0382 * * \\
(-0.016)\end{array}$ & $\begin{array}{l}-0.0350 * * \\
(-0.010)\end{array}$ & $\begin{array}{l}0.0384 \\
(1.348)\end{array}$ & $\begin{array}{l}0.0429^{* *} \\
(0.019)\end{array}$ \\
\hline Reform $*$ FOF & & & & & $\begin{array}{l}-0.039^{* *} \\
(0.016)\end{array}$ \\
\hline SGrowth & $\begin{array}{l}0.140 * * * \\
(0.061)\end{array}$ & $\begin{array}{l}0.034^{* *} \\
(0.021)\end{array}$ & $\begin{array}{l}0.033^{* *} \\
(0.010)\end{array}$ & & \\
\hline Reform $*$ SGrowth & $\begin{array}{l}0.4096^{* * * *} \\
(-0.056)\end{array}$ & $\begin{array}{l}0.3428 \\
(1.98)\end{array}$ & & & \\
\hline Illiquidity & $\begin{array}{l}-0.374^{* * *} \\
(-0.096)\end{array}$ & $\begin{array}{l}-0.346^{* * *} \\
(-0.16)\end{array}$ & $\begin{array}{l}-0.446^{* * * *} \\
(0.139)\end{array}$ & $\begin{array}{l}-0.483^{* * * *} \\
(0.128)\end{array}$ & $\begin{array}{l}-0.563^{* *} \\
(0.128)\end{array}$ \\
\hline Reform*Illiquidity & & & $\begin{array}{l}3.707^{* * *} \\
(2.72)\end{array}$ & $\begin{array}{l}3.570^{* * * *} \\
(2.61)\end{array}$ & \\
\hline LegTA & $\begin{array}{l}0.035^{* * * *} \\
(4.25)\end{array}$ & $\begin{array}{l}0.035^{* * * *} \\
(3.46)\end{array}$ & $\begin{array}{l}0.035^{* * *} \\
(2.45)\end{array}$ & $\begin{array}{l}0.035^{* * * *} \\
(5.23)\end{array}$ & \\
\hline $\mathrm{ROA}$ & $\begin{array}{l}0.351^{* * * *} \\
(3.94)\end{array}$ & $\begin{array}{l}0.3891 \\
(4.91)\end{array}$ & $\begin{array}{l}0.4038 \\
(1.60)\end{array}$ & $\begin{array}{l}0.3298 \\
(3.58)\end{array}$ & \\
\hline Cash & $\begin{array}{l}0.245^{* * *} \\
(7.62)\end{array}$ & $\begin{array}{l}0.247 * * * \\
(4.55)\end{array}$ & $\begin{array}{l}0.246^{* * * *} \\
(3.59)\end{array}$ & $\begin{array}{l}0.244 * * * \\
(2.53)\end{array}$ & \\
\hline Leverage & $\begin{array}{l}-0.265^{* * *} \\
(-10.61)\end{array}$ & $\begin{array}{l}-0.262^{* * *} \\
(10.49)\end{array}$ & $\begin{array}{l}-0.267 * * * \\
(-10.67)\end{array}$ & $\begin{array}{l}0.264 * * * \\
(-10.57)\end{array}$ & \\
\hline ROAVOL & $\begin{array}{l}-1.048^{* * * *} \\
(-6.47)\end{array}$ & $\begin{array}{l}-1.043^{* * * *} \\
(-6.52)\end{array}$ & $\begin{array}{l}-1.045^{* * * *} \\
(-6.50)\end{array}$ & $\begin{array}{l}-1.041 * * * \\
(-6.47)\end{array}$ & \\
\hline RE2TE & $\begin{array}{l}0.372^{* * * *} \\
(11.67)\end{array}$ & $\begin{array}{l}0.371^{* * * *} \\
(11.68)\end{array}$ & $\begin{array}{l}0.376^{* * *} \\
(11.79)\end{array}$ & $\begin{array}{l}0.394^{* * * *} \\
(11.79)\end{array}$ & \\
\hline LagPayout & $\begin{array}{l}0.5482^{* *} \\
(0.206)\end{array}$ & $\begin{array}{l}0.5763^{* * *} \\
(0.182)\end{array}$ & $\begin{array}{l}0.5083^{* *} \\
(0.158)\end{array}$ & $\begin{array}{l}0.5902^{*} \\
(2.09)\end{array}$ & $\begin{array}{l}0.5706 \\
(3.09)\end{array}$ \\
\hline Goodevn & $\begin{array}{c}0.03637^{* *} \\
(0.007)\end{array}$ & $\begin{array}{c}0.02864^{* *} \\
(0.014)\end{array}$ & $\begin{array}{c}0.01268^{* * * *} \\
(0.023)\end{array}$ & $\begin{array}{c}0.12463^{* * *} \\
(0.048)\end{array}$ & $\begin{array}{l}0.10056^{*} \\
(0.060)\end{array}$ \\
\hline
\end{tabular}

